\title{
Brain Drain Migration from Romanian Academia. The End of a Mirage
}

\author{
CiprianPanzaru ${ }^{1,2}$ \\ Robert D. Reisz ${ }^{3}$ \\ ${ }^{1}$ Department of Sociology, West University of Timisoara, Romania \\ ${ }^{2}$ Research Group on Social and Economic Complexity, West University of Timisoara, Romania \\ ${ }^{3}$ Department of Political Sciences, West University of Timisoara, Romania
}

(C) 2017 Ciprian Panzaru, Robert D. Reisz

This is an open access article distributed under the Creative Commons Attribution-NonCommercial-NoDerivs license (http://creativecommons.org/licenses/by-nc-nd/3.0/)

DOI: $10.1515 /$ eras-2017-0003

\begin{abstract}
The article is focused on the image of migration that Romanian academics transmit through the invisible curricula of the universities. These opinions are bound to become vectors of the future behaviour of graduates and legitimate a certain approach to brain drain. The goal of the research was to find how opinions and intentions on migration changed between 2000 and 2013 and what possible explanations can be found for these changes. The analysed data were collected in two sample surveys, one conducted in 2000 and another one in 2013. The results clearly show that there is an impressive change in the interest of Romanian academics to emigrate. Information and personal experience on migration and international mobility have become pervasive in the higher education system. Migration as a mirage, as a temptation not fully understood, does not exist anymore in Romanian higher education.
\end{abstract}

Keywords: international migration, brain drain, Romanian Academia, human capital

\section{Introduction}

International migration has increased considerably in recent years. The phenomenon has grown progressively and was boosted by geopolitical changes occurring in Eastern Europe in the late ' $80 \mathrm{~s}$. The fall of communist regimes in Europe has allowed the free movement of citizens of these countries. This new migration boom has attracted the attention of scientists but also of policy makers. One of the issues raised by migration studies was whether it has a positive or negative effect on the migrant's country of origin. The answer to this question can be found in the analysis of two main dimensions: who are those who migrate and why do they leave. At first glance, migration can be regarded as a phenomenon that generates positive effects in the country of origin of migrants. Thus, migration can be an outlet which reduces the pressure on resources (food, territory), diminishes the possibility of social conflict (by the unhappy leaving), reduces labor market imbalances (by the unemployed leaving), etc. However, among the millions of migrants there are countless highly educated people who choose to leave usually less developed countries, already deficient in terms of the quality of human resources, turning to developed countries where the need for human capital and skilled workers is higher. Individuals who leave are carriers of know-how, which is an economic value because the country of origin has invested in their education and training. The higher the educational level of those who leave, the greater the loss for the country of origin. It does not only loose workforce but also the investment made with their education and training. Therefore, the effect of brain drain is often a negative effect on the country of origin. In fact, this is the basic cost associated with migration for the country of origin. Brain drain does not only entail highly skilled persons' mobility but also the mobility of know-how. In 
addition, it is not associated only with knowledge and skills acquired through education, but it also has a political value. For example, the fact that the educated leave mostly poor countries reduces these countries' chances of reform.

Regarding Romania, there are no data on the size of this phenomenon. There are no very precise statistics on the number of Romanian specialists by socio-professional category who chose to go abroad, but only general data on which we can infer the extent of the phenomenon. We know, for example, that after 2007, more than 14,000 physicians have left Romania. Almost 3,000 of them have gone in 2013. A simple calculation on the costs of education shows that the state has invested about 3.5 billion Euros in their training (Romanian College of Physicians).

The present paper deals with the phenomenon of brain drain migration by studying Romanian academics. There are many reasons for choosing this segment of the population. On the one hand, academics themselves count not only as an elite segment of a society, but are also those who educate the specialists of tomorrow, participate in science and technology production and even in the definition of scientifically valid knowledge. Their departure can cause consistent imbalances in society as it leads to a decrease in specialist expertise, highly affecting the socio-economic component of sustainable development. On the other hand, academics are important to our subject because of their role as opinion leaders. Their attitude towards migration can be a factor that influences other audiences, which is transmitted to both students and the rest of the public. In this approach, two questions were addressed: (1) what is the opinion on and interest in migration of Romanian academics? and (2) what factors determine the decision to migrate?

The paper is organized as follows: In Section 2, we review the literature on brain drain migration and its effects. Section 3 describes our research methodology, including data collection, construction, measurement and results. Section 4 presents conclusions and the main implications of the findings.

\section{Literature Review}

There is no certainty regarding the origin of the term brain drain. Some sources believe that the term was first used by the British Royal Society (Cervantes \& Guellec, 2002) to describe the post war migration of researchers from the UK to the U.S. and Canada. Other researchers (Spring, 2008) believe that the term was used to describe the influx of specialists from India to the UK.

However, the fact is that the first debate on the brain drain phenomenon emerged in the '50s. One of the earliest studies is that of Brinley Thomas (1958). He published in the Economics of International Migration, a paper on the skills and education of immigrants, without making reference directly to the migration of researchers, scientists or other highly qualified people. The debate on the Brain Drain phenomenon has been exacerbated by the emergence in 1963 of the report entitled The Emigration of Scientists from the United Kingdom, conducted by the Royal Society. The study emerged in response to a series of articles and analysis published in the press and has generated in turn numerous research studies. In 1965, Harry G. Johnson published the study "The economics of the brain drain: The Canadian case", followed a few years later, in 1968, by the paper "The Brain Drain", published by Walter Adams, a paper that will later on be considered by some authors (Grubel $\&$ Scott, 1977) as one of the few books that deal directly and exclusively with the brain drain phenomenon. Also in 1968, Grubel published the article "The reduction of the brain drain: problems and policies". In fact, Grubel and Scott have conducted extensive research on international migration in the United States and the Brain Drain phenomenon (1949-1961, 
1966, 1967, 1977). Their research has generated numerous debates among economists, primarily on the effects of the phenomenon on welfare in countries of origin of migrants and in their countries of destination. Moreover, in the '70s there was an explosion of research on the Brain Drain phenomenon and its implications. This was manifested mainly in the United States, also generated by the 1965 issuance of the Immigration and Nationality Act (1965). The Act, known as the Hart Celler Act, named after the two congressmen who initiated it (Emanuel Celler \& Philip Hart), proposes a system for selecting immigrants taking into account, inter alia, their skills. In 1970, Bernard makes an analysis of the connection between this Act and the Brain Drain phenomenon, showing that the emphasis laid by the Immigration Act on the talent and skills of immigrants has generated a major reconfiguration of their demographic characteristics. In 1973, Friedman performs a research focused on the dynamics of flows of immigrants from less developed countries as a result of this Act. Keely (1971, 1975) examines the effects of the Immigration Act on the socio-demographic composition of immigrants in the United States.

The ' 80 s mark a consistent emergence of Brain Drain phenomenon debates in international institutions. In the International Conference on Population 1984, the Chapter Recommendations addresses specifically the Brain Drain issue, making recommendations on the development of appropriate policies to limit the Brain Drain phenomenon from developing countries to developed countries. At the same time, however, the term Brain Drain is coupled with another two concepts (Giannoccolo, 2004): Brain exchange and Brain Drain waste. Johnson \& Regets (1998) have also introduced the concept of Brain Circulation.

If during the ' $80 \mathrm{~s}$ and early ' $90 \mathrm{~s}$, the Brain Drain phenomenon debates were developed mainly in conjunction with population movements from Asia and Africa (to the United States and Europe), after the '90s discussions focused on Europe and intercontinental migration. In 2003, Richard H. Adams Jr. conducts an extensive research on the extent of the Brain Drain phenomenon in OECD countries. He showed that Brain Drain is associated with legal migration, but the most important aspect found by him, however, is that geographic proximity facilitates skilled migration.

During this period, cost-benefit debates stand out in terms of the Brain Drain phenomenon. Although for longtime, studies have addressed Brain Drain as a serious limitation to developing states faced with this phenomenon (Ozden \& Schiff, 2006), there are approaches that emphasize the positive aspects of the phenomenon. Oded Stark (2004), in "Rethinking the Brain Drain", speaks of two types of human capital: a general one and a specific one. The latter becomes productive only abroad, while in the country of origin it is useless. As such, migration controlled by appropriate policies can contribute to the higher welfare of individuals than the lack thereof.

Beine et al. (2008), in a cross-sectional research conducted in 2008 in 127 countries, found that Brain Drain migration "contributes to an increase in the number of skilled workers living in the developing countries".

The expansion of the European Union since 2004 to Eastern Europe has generated new flows of migrants (Eurostat, 2014). Research conducted during this period has the advantage of bringing to the fore real and current cases. Anniste et al. (2012) conducted a case study focused on emigration from Estonia, but their results reveal a low level of brain drain migration from Estonia to Western Europe after 2004 when the country joined EU. Instead, Nicholas P. Glytsos (2010), analyzing the case of Bulgaria and Albania, found that these countries were marked to a great extent by substantial volumes of highly educated population leaving the country. In fact, these two countries have also been analyzed earlier (Docquier \& Marfouk, 2004) who calculated that skilled emigration rate in 2000 was $20 \%$ for Albania and $5.8 \%$ for Bulgaria. 
In this context, Romania is placed as a country that has generated a large number of immigrants. In fact, Romania is the country with most emigrants. In 2013, the EU registered 2.3 million emigrants coming from Romania (Eurostat, 2014). How many of them are skilled migrants? Hard to say, but bear in mind that the European Union becomes a favorable environment for highly qualified migration. The European Union's objective of achieving a single labor market will face labor shortages (Zimmermann, 2013), highly qualified, average qualified or unqualified. An incentive of highly qualified labor mobility can also be represented by the huge budget allocated by the EU for research (60 billion Euros) for the period 2014-2020. This is likely to worry particularly the states which will not be able to absorb these funds, which will be only migrant-sending countries (Gibson \& McKenzie, 2011).

\section{Results of the Survey}

\subsection{Statistical sources}

The data analyzed were collected in two research steps, one conducted in 2000 and another one in 2013. We have used the same questionnaire. These data were compared with each other. The investigated population was represented by the academics from Romanian universities. The size of the sample was 209 in 2000 and 266 in 2013 . We have used a stratified sample reflecting the distribution of higher education institutions in Romania.

While changes in the opinions about emigration have been less significant, there is an impressive change in the interest of Romanian academics to emigrate. The goal of the present paper is to find how this change can be explained, or at least to find explanations that can clearly be refuted and to reduce the scope of possible causes.

\subsection{Motility}

To compute interest to emigrate in a simple form, we have devised an indicator based on a Guttman scale comprising of 4 logically ordered questions that ask about the intention to emigrate in different condition. We start with a maximal support alternative: "would you emigrate if you would have guaranteed a job and a place to stay abroad?" and end with the minimal form ,would you emigrate if you have no guaranteed job or a place to stay?“. While this formulation might sound somewhat forced, the gradual order of the questions enables a fine positioning of individual intention to emigrate. We have added up the answers to obtain a scale we have named "motility". The overall distribution of motility is presented in the figure 1, below:

\begin{tabular}{ccccc}
0 & 1 & 2 & 3 & 4 \\
\hline 43.4 & 24.4 & 24.0 & 6.1 & 2.1
\end{tabular}

Figure 1. The scale of motility (\%)

The largest part of our sample has no intention of emigrating even in the best of conditions. There are only 10 persons (roughly $2 \%$ of the sample) that would emigrate in any conditions. Comparing the indicator for the two samples, the one questioned in 2000, and the one questioned in 2013 we find that the difference is striking and statistically highly significant (Chi2 Sig $=0$ 0.000). The results, for each year are presented in the figure 2. 


$\begin{array}{ccccc}2000 & & & & \\ 0 & 1 & 2 & 12.0 & 1.9 \\ 46.4 & 12.9 & 26.8 & & \\ 2013 & & & 3 & 4 \\ 0 & 1 & 2 & 1.5 & 2.3\end{array}$

Figure 2. The scale of motility (comparison between 2000 and 2013) (\%)

The proportion of low motility (values 0 and 1) persons was roughly $60 \%$ of the sample, while in 2013 it has increased to $74.5 \%$. High motility (values 3 and 4) characterized $13.9 \%$ of the 2000 sample, while 2013 it is to be found at only $3.8 \%$.

\subsection{Rootedness}

Another question complementing the ones above asked if a person agrees to the sentence "I would not emigrate, no matter what". For simplicity, we will name this indicator, rootedness. The value of the rootedness for 2000 and 2013 are presented in the Graph 1.

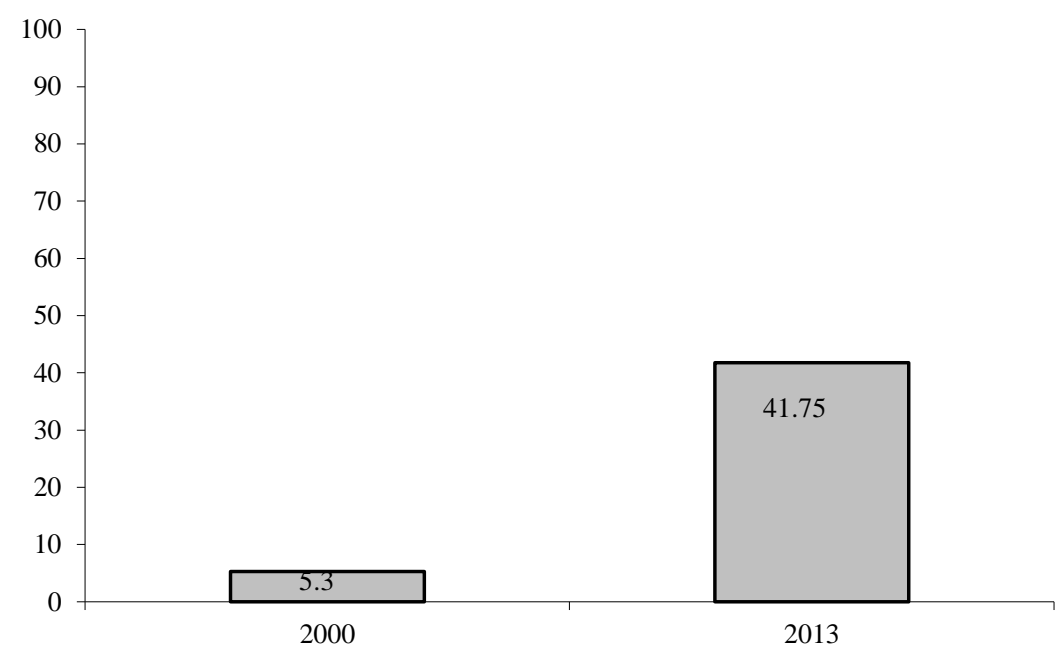

Figure 3. The value of the rootedness (comparison between 2000 and 2013) (\%)

Here as well the difference is radical and highly significant. While in 2000, only 11 persons were fundamentally against emigrations, the number increased tenfold in the 2013 sample. In proportions, the increase is from 5\% to $42 \%$.

Motility vs. Rootedness - the role of the age groups and academic disciplines

The immediate question is if these differences between the 2000 and the 2013 samples might result from differences in the characteristics of the samples or of the overall staffing system of higher education. Before concluding that a change of in the opinions of Romanian academics had taken place we must eliminate obvious statistical-methodological explanations as well as real changes in the overall structure of higher education personnel. It might be the case that opinions have not changes relevantly but that the samples or the overall population 
has changed in its composition. So, age groups could have changed in proportions, academic positions or disciplines could have changed in proportion. We have investigated these elements point by point. We found that age distribution has indeed changed, as the graph 2 also clearly shows. What has obviously taken place is a shift of the modal age group.

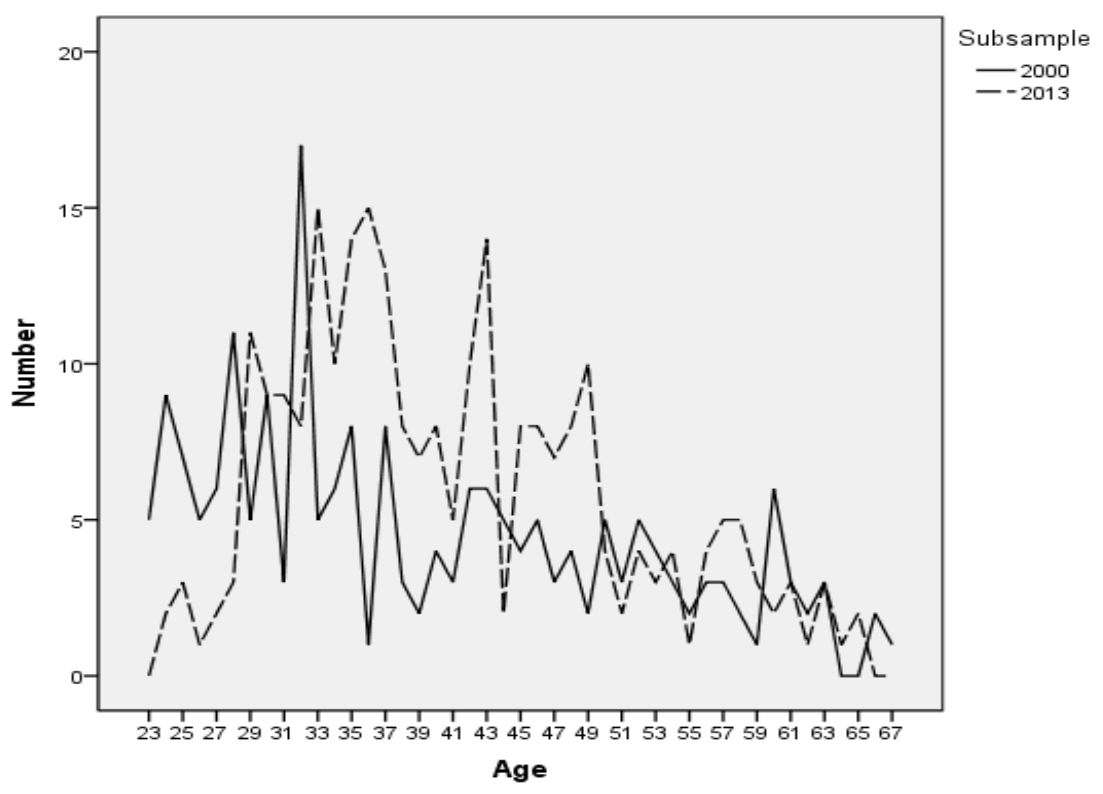

Figure 4. Age distribution

In age decades, the trends become simpler and clearer, see figure 3.

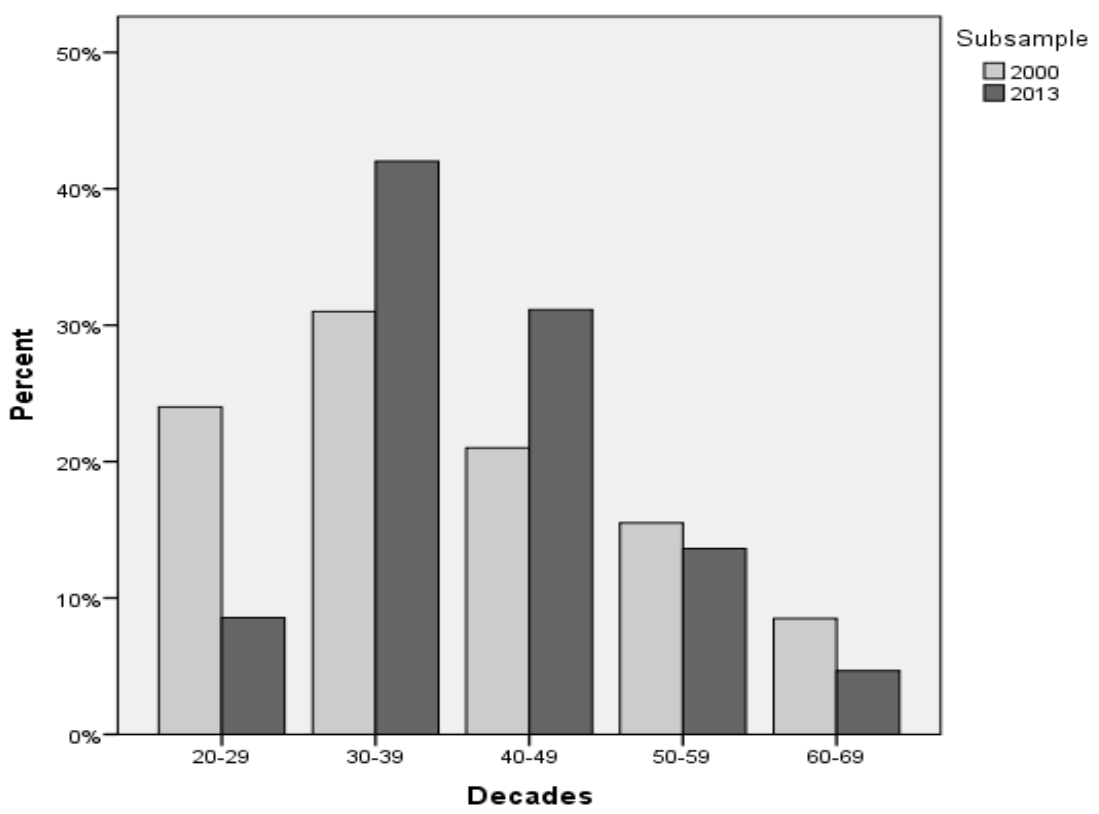

Figure 5. Age distribution

This change in age proportions might explain generally the change in motility and rootedness even if there was no change in opinions. The table 1 shows nevertheless that age 
group averaged motility values have indeed changed a lot. What is surprising is that the average values remain more or less equal of the extremal decades, those in their $20 \mathrm{~s}$, in their 50s and 60s have the same motility values in both subsamples, while for the core of the sample, the academics in their 30 s and 40 s (50\% of the sample in $2000,70 \%$ in 2013) the differences are radically lower in the second sample.

\begin{tabular}{cccc} 
Motility & & & \\
\hline Subsample & Decade & Average & $\begin{array}{c}\text { Standard } \\
\text { deviation }\end{array}$ \\
\hline \multirow{2}{*}{2000} & $20-29$ & 1.08 & 1.200 \\
& $30-39$ & 1.35 & 1.216 \\
& $40-49$ & 1.26 & 1.106 \\
& $50-59$ & 0.94 & 1.153 \\
2013 & $60-69$ & 0.41 & 0.870 \\
& $20-29$ & 1.09 & 0.750 \\
& $30-39$ & 0.94 & 0.895 \\
& $40-49$ & 0.79 & 1.027 \\
& $50-59$ & 0.97 & 1.043 \\
& $60-69$ & 0.42 & 0.515 \\
\hline
\end{tabular}

Table 1. Age group averaged motility

No similar results can be found for rootedness, as we can see in the table 2. Here the differences between subsamples are radical for all age groups.

\begin{tabular}{lllc} 
Rootedness & Decade & Average & $\begin{array}{c}\text { Standard } \\
\text { deviation }\end{array}$ \\
\hline \multirow{2}{*}{2000} & $20-29$ & 0.063 & 0.245 \\
& $30-39$ & 0.048 & 0.216 \\
& $40-49$ & 0.048 & 0.216 \\
& $50-59$ & 0.065 & 0.250 \\
2013 & $60-69$ & 0.059 & 0.243 \\
\hline & $20-29$ & 0.227 & 0.429 \\
& $30-39$ & 0.380 & 0.488 \\
& $40-49$ & 0.513 & 0.503 \\
& $50-59$ & 0.457 & 0.505 \\
& $60-69$ & 0.583 & 0.515 \\
\hline
\end{tabular}

Table 2. Age group averaged rootedness

The overall conclusion is that the changes in age proportions in the two subsamples are not enough to explain the overall change in opinion distribution.

We have tested a similar hypothesis for the impact of academic disciplines. If disciplinary cultures have different ideologies on emigration and rootedness, their changes in proportion, be it real or through sampling bias would lead to changes in the overall distribution of motility and rootedness values. In such a case, it could happen that average motility remains more or less the same within a discipline, and the change in the proportion of the discipline explains the overall change. This is not the case. The average motility values for 
disciplinary categories have changed themselves in important degrees. (the Mann-Whitney tests for each discipline have significant values).

Motility and Rootedness - other determinants: age, academic positions, personal experience with migration and the social network's experience

What is it nevertheless, that led to the change? We will start our investigation by analyzing one step further the relationship that age has with motility. Let us correlate motility with age to see if the effect of age upon motility has changed and how important it is. As motility is an ordinal variable, we have decided to use Spearman's Rho, see table 3. We found an overall weak correlation of -0.122 having nevertheless, a good significance.

\begin{tabular}{lcc} 
Correlations (Spearman-Rho) & \\
\hline & 1 & 2 \\
\hline Age & - & - \\
Motility & $-0.122^{* *}$ & \\
$* * \mathrm{p}<0.01$ level & \\
$* \mathrm{p}<0.05$ level &
\end{tabular}

Table 3. Correlation between age with motility

The relationship with rootedness is also significant, as we can see in the table 4 . The mean age difference between more or less rooted persons is not high but statistically relevant. The average age of those that would not migrate, no matter what opportunity they would be given is a little above 42 years, while the average age of the comparison group is somewhat below 40.

\begin{tabular}{|c|c|c|c|c|c|c|}
\hline & Rootedness & Average & Standard deviation & $\begin{array}{l}\text { Standard error of the } \\
\text { mean }\end{array}$ & F test & Sig. \\
\hline \multirow[t]{2}{*}{ Age: } & No & 39.69 & 10.842 & 0.592 & \multirow{2}{*}{3.012} & \multirow{2}{*}{0.083} \\
\hline & Yes & 42.39 & 9.768 & 0.888 & & \\
\hline
\end{tabular}

Table 4. The average ages of rooted people

Let us now analyze these effects separately on the two samples. The correlations in the table 5 find no significant statistical correlation for the 2000 subsample and a weak and weakly significant correlation for the 2013 subsample. The somewhat more significant overall correlation has proven to be more or less artefactual.

\begin{tabular}{|c|c|c|c|}
\hline & & 1 & 2 \\
\hline \multirow{2}{*}{2000} & Age & - & \\
\hline & Motility & -0.093 & - \\
\hline \multirow{2}{*}{2013} & Age & - & \\
\hline & Motility & $-0.131 *$ & - \\
\hline
\end{tabular}

Table 5. Correlation between age with motility (2000 and 2013) 
Analyzing the average ages of rooted and non-rooted groups we find that for the 2000 subsample the difference is not significant, while for the 2013 subsample there is a weak significance. This parallels results before, age gaining importance in the second sample. The results are presented in the table 6 .

\begin{tabular}{lllcccc}
\hline \multirow{2}{*}{ Year } & Rootedness & & Standard deviation & $\begin{array}{c}\text { Standard error of the } \\
\text { mean }\end{array}$ & F test & Sig \\
\hline \multirow{2}{*}{2000} & No & 39.54 & 11.815 & 0.859 & 0.029 & 0.865 \\
& Yes & 38.91 & 12.284 & 3.704 & & \\
& & & & & & \\
2013 & No & 39.88 & 9.482 & 0.782 & 0.007 & 0.935 \\
& Yes & 42.74 & 9.480 & 0.904 & & \\
\hline
\end{tabular}

Table 6. The average ages of rooted and non-rooted groups

Still the overall importance of age as a correlate of motility and rootedness is very low. This situation is surprising as literature generally finds that age is an important, if not maybe the most important predictor for mobility. There are two hypothetical explanations for this surprising result. On the one hand, we investigate not mobile persons, but persons that declare intention of mobility. On the other hand, and according to our opinion more importantly, the structure of the academic profession replaces age as a predictor with academic position. High academic positions have good stability and good future prospects regardless of age, while lower positions are unstable also regardless of age. The academic staffing system that relies on the academic career ladder is less age dependent now than before and less age dependent than other professional careers. Academic position is as such a very good indicator for job stability.

Let us than make this step and compare the samples in the way academic position related to motility, see table 7 .

\begin{tabular}{|c|c|c|c|c|c|c|}
\hline Subsample & Motility & & & & & \\
\hline \multirow{6}{*}{2000} & & 0 & 1 & 2 & 3 & 4 \\
\hline & $\begin{array}{ll}\text { Junior } & \text { teaching } \\
\text { assistant* }\end{array}$ & 19.60 & 37.00 & 8.90 & 16.00 & 0.00 \\
\hline & Teaching assistant & 14.40 & 11.10 & 21.40 & 36.00 & 75.00 \\
\hline & Lecturer & 20.60 & 22.20 & 44.60 & 28.00 & 0.00 \\
\hline & Associate professor & 15.50 & 14.80 & 8.90 & 12.00 & 25.00 \\
\hline & Professor & 27.80 & 14.80 & 14.30 & 8.00 & 0.00 \\
\hline \multirow{4}{*}{2013} & Teaching assistant & 12.80 & 25.80 & 22.40 & 25.00 & 0.00 \\
\hline & Lecturer & 36.70 & 40.40 & 39.70 & 50.00 & 66.70 \\
\hline & Associate professor & 32.10 & 21.30 & 29.30 & 25.00 & 33.30 \\
\hline & Professor & 17.40 & 11.20 & 6.90 & 0.00 & 0.00 \\
\hline
\end{tabular}

*The academic position "Junior teaching assistant" has been eliminated according to the Education Law no. 1/2011.

Table 7. Comparison between academic position and motility (2000 and 2013) (\%) 
The Chi2 Sig for the 2000 sample finds a relevant relationship (0,006), while for 2013 the relationship is not significant $(0,536)$, see table 8 .

\begin{tabular}{lllll}
\multicolumn{2}{c}{ Chi-Square Tests } & & & \\
\hline \multirow{2}{*}{2000} & Pearson Chi-Square & $39.564 \mathrm{a}$ & 20 & 0.006 \\
& Likelihood Ratio & 38.871 & 20 & 0.007 \\
& & & & \\
\multirow{2}{*}{2013} & Pearson Chi-Square & 16 & 16 & 0.536 \\
& Likelihood Ratio & 17.315 & 16 & 0.365 \\
\hline
\end{tabular}

Table 8. Chi-Square tests for relationship between academic position and motility (2000 and 2013)

Similar results can be found for the relationship between academic position and rootedness. The Chi2 significance for the 2000 subsample is 0.021 , while for the 2013 subsample it is 0.119 . Adding these results to the upper ones we find that there is a clear change in the predictors of motility and rootedness. While in 2000 academic position was clearly more important than age, in 2013 it is age that gained a certain impact, while academic position has lost its importance.

An essential determinant for migration intent and ideology might be the personal experience with migration and mobility as well as the social network's experience.

Let us first study the relationship between motility and the duration of the longest stay abroad. The correlations are shown in the table 9.

\begin{tabular}{|c|c|c|c|}
\hline \multicolumn{4}{|l|}{ Correlations } \\
\hline Subsample & & 1 & 2 \\
\hline \multirow{2}{*}{2000} & $\begin{array}{l}\text { What was the longest period that you have spent } \\
\text { abroad (months)? }\end{array}$ & - & \\
\hline & Motility & -0.008 & - \\
\hline \multirow[t]{2}{*}{2013} & $\begin{array}{l}\text { What was the longest period that you have spent } \\
\text { abroad (months)? }\end{array}$ & - & \\
\hline & Motility & $0.197 * *$ & - \\
\hline
\end{tabular}

Table 9. Correlation between motility and duration (2000 and 2013)

We find no correlation in the 2000 subsample and a weak, positive and significant correlation for the 2013 subsample. Taking the number of visits abroad, and indicator of academic mobility, see table 10 , we find also no correlation. 


\begin{tabular}{|c|c|c|c|}
\hline \multicolumn{4}{|c|}{ Correlations (Spearman-Rho) } \\
\hline Subsample & & 1 & 2 \\
\hline \multirow{2}{*}{2000} & How many visits abroad have you had in the last 5 years? & - & \\
\hline & Motility & 0.067 & - \\
\hline \multirow{2}{*}{2013} & How many visits abroad have you had in the last 5 years? & - & \\
\hline & Motility & -0.059 & - \\
\hline
\end{tabular}

Table 10. Correlation between motility and number of visits abroad (2000 and 2013)

Taking another approach, let us compare the mean motility for groups of academics according to their mobility. The results are shown in the table 11.

\begin{tabular}{llcc}
2000 & & & \\
Motility & Average & Standard deviation & ANOVA sig. \\
\hline How many visits abroad have you had in the last 5 years? & 1.29 & 1.367 & 0.287 \\
None & 0.98 & 1.149 & \\
$1-5$ & 1.32 & 1.141 & \\
$6-10$ & 1.25 & 1.164 & \\
Over 10 & & & \\
\hline 2013 & & & ANOVA sig. \\
Motility & Average & Standard deviation & \\
\hline How many visits abroad have you had in the last 5 years? & 0.55 & 0.688 & \\
None & 0.97 & 0.932 & \\
$1-5$ & 0.99 & 0.950 & \\
$6-10$ & 0.78 & 0.967 & \\
Over 10 & & & \\
\end{tabular}

Table 11. Mean motility for groups of academics according to their mobility (2000 and 2013)

We find again that the personal experience of mobility does not explain motility for our data. This leads us to the intermediary conclusion that it is not the change in personal experience that determined the change in motility for Romanian academics. It is not that they have more or less experience with international mobility that leads to their changed intention to migrate.

It seems that neither time spent abroad nor the number of visits made is a good predictor for motility. If for the research conducted in 2000 the stated maximum number of months spent abroad was 1,084, respondents in 2013 said they had spent at most a total of 2,303 months abroad. Regarding the number of visits, for example in 2000 only $9.6 \%$ said they had made more than 10 visits abroad, while in 2013 this percentage increased to $27.1 \%$. This dynamic is actually an increase in opportunities to go abroad for internships, grants, collaborations, etc. The existence of these opportunities diminishes the desire to emigrate for a very simple reason: now, there is the opportunity to go abroad at any time for those who want it, but, at the same time, there is the possibility of maintaining their academic position in Romania. Amid changes to the structure of the academic profession we note that for 2013 there is a consistent component of teachers holding secondary and upper level academic 
positions (assistant professors - associate professors - professors), positions considered relatively stable associated with a low motivation to emigrate.

Another essential hypothesis is that it is not the first had experience that influences the intention to migrate, but the experience of the social network of the interview partner.

The migrant's social network is represented by those interpersonal relationships through which migrants, former migrants and non-migrants in the country/region of destination and origin are brought into contact. Therefore, the decision to migrate depends largely on the existence of contacts abroad. In our analysis, we included in this category the collaboration with foreign academics (researchers), the existence of other emigrants among relatives and friends, the relationship with migrant acquaintances.

Here again no significant relationships are to be found. Foreign ties are not a significant factor in the decision to emigrate, as we can see in the table 12.

2000

Motility * How many foreign researchers or teachers do you collaborate with?

\begin{tabular}{|c|c|c|c|}
\hline How many foreign researchers or teachers do you collaborate with? & Average & Standard deviation & ANOVA sig. \\
\hline $1-3$ & 1.1 & 1.172 & 0.685 \\
\hline $4-6$ & 0.97 & 1.135 & \\
\hline Over 7 & 1.28 & 1.246 & \\
\hline None & 1.03 & 1.158 & \\
\hline
\end{tabular}

Motility * Do you have friends or relatives who have emigrated?

\begin{tabular}{lcc}
\hline Do you have friends or relatives who have emigrated? & Average & Standard deviation \\
\hline Yes & 1.13 & 1.179 \\
No & 0.88 & 1.177 \\
\hline
\end{tabular}

Motility * Which is your actual relationship with your friends who have emigrated?

\begin{tabular}{|c|c|c|c|}
\hline Which is your actual relationship with your friends who have emigrated? & Average & Standard deviation & ANOVA sig. \\
\hline Frequent & 1.15 & 1.146 & 0.721 \\
\hline Occasionally & 1.1 & 1.177 & \\
\hline None & 1.12 & 1.409 & \\
\hline
\end{tabular}

2013

Motility * How many foreign researchers or teachers do you collaborate with?

\begin{tabular}{|c|c|c|c|}
\hline How many foreign researchers or teachers do you collaborate with? & Average & Standard deviation & ANOVA sig. \\
\hline $1-3$ & 0.9 & 0.861 & \multirow{4}{*}{0.909} \\
\hline $4-6$ & 1.02 & 1 & \\
\hline Over 7 & 0.85 & 1.038 & \\
\hline None & 0.88 & 0.956 & \\
\hline
\end{tabular}

Motility * Do you have friends or relatives who have emigrated?

\begin{tabular}{lcc}
\hline Do you have friends or relatives who have emigrated? & Average & Standard deviation \\
\hline Yes & 0.94 & 0.963 \\
No & 0.63 & 0.273 \\
\hline
\end{tabular}

Motility * Which is your actual relationship with your friends who have emigrated?

\begin{tabular}{lccc}
\hline $\begin{array}{l}\text { Which is your actual relationship with your friends who have } \\
\text { emigrated? }\end{array}$ & Average & Standard deviation \\
\hline $\begin{array}{l}\text { Frequent } \\
\text { Occasionally }\end{array}$ None & 0.91 & 0.933 \\
\hline
\end{tabular}

Table 12. Collaboration with foreign academics (2000 and 2013) 
What remains? As we have seen important predictors of mobility in general seem not to work on the intention of Romanian academics to migrate and fail to explain why this intention has changed so much in the decade between the two data collections. Age, academic position (as a proxy for job security and prestige), personal experience on mobility, social network mobility has no significant impact on motility.

\section{Conclusions}

It seems that the important changes in the intention to migrate of Romanian academics in the period between 2000 and 2013 are not easily explained by age, status and personal or social experience. Migration studies literature finds few other important individual predictors. Weak conclusions would pass the explanation to social factors, to the changes that have taken place in Romanian and European societies and politics. And even if our data are not enough to test such hypotheses, we are tempted to find such explanations are temporarily acceptable.

A little light could be shed further on the subject by proposing a typology. Let us look at the relationship between intention to migrate and information, personal and social. We have constructed two indicators, mobility: grouping the two higher values and the two lower values of the motility scale and information: adding all questions on direct and indirect information on migration and splitting the resulting scale in two.

This led to the matrixes from figure 4 for 2000 and 2013.

What this representation clearly shows are three effects:

- The number of academics that consider it possible to migrate has decreased relevantly

- The group of less informed, but mobile persons has practically disappeared.

- The proportion of academics having international experience has increased a lot.

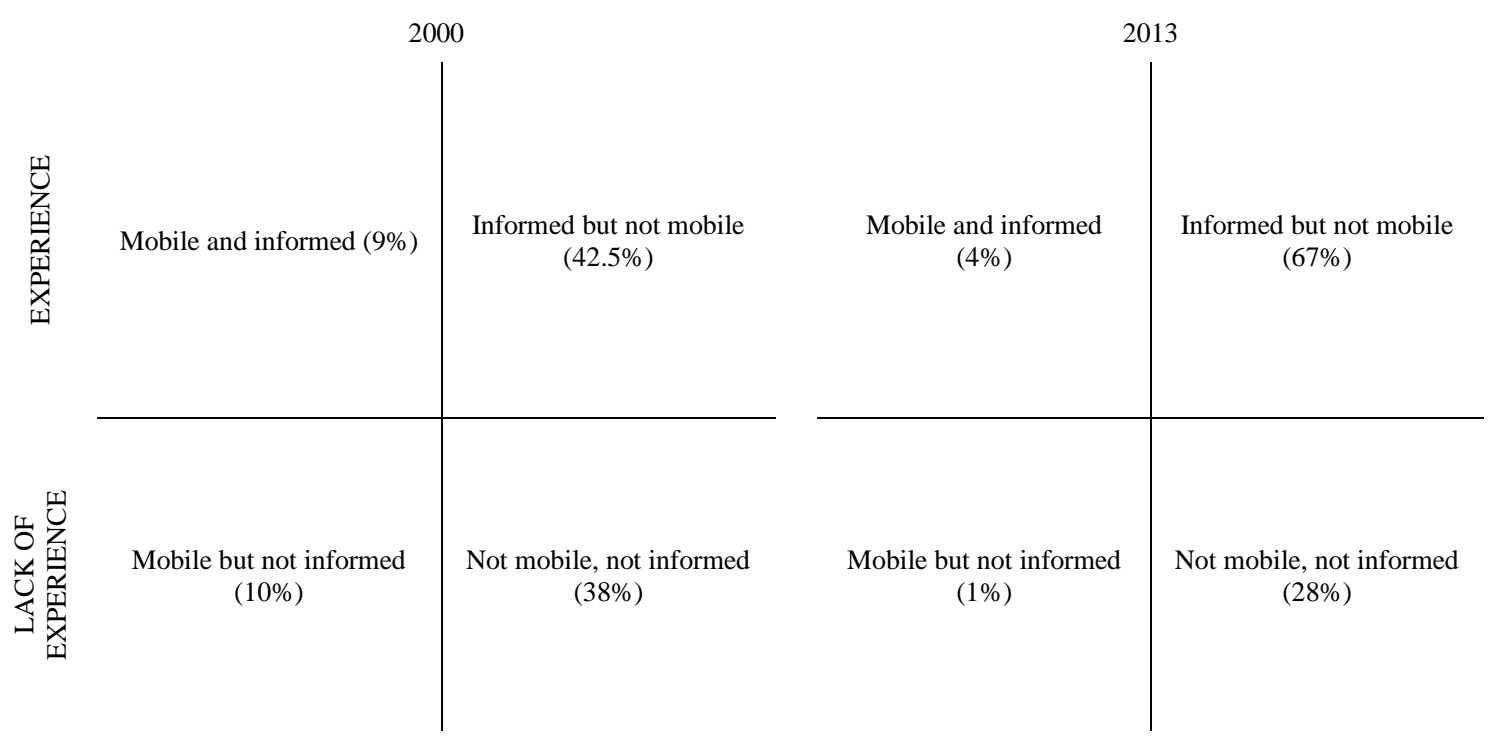

Figure 6: Typology of the Romanian Academics in the light of motility (2000 and 2013) 
Let us propose a hypothesis: while information in itself does little in helping to explain motility, the fact that information and personal experience on migration and international mobility has become pervasive in the higher education system has made a certain relationship to migration disappear.

We can conclude that migration as a mirage, as a temptation not fully understood, does not exist anymore in Romanian higher education.

This leads to another conclusion: a policy of support for international academic relations and openness towards international collaboration can also have effects on the reduction of brain drain.

\section{References}

Adams Jr, R. H. (2003). International migration, remittances, and the brain drain: A study of 24 laborexporting countries. Washington: World Bank. https://openknowledge.worldbank.org/handle/10986/18161.

Adams, W. (1968), The brain drain. New York: Macmillan.

Anniste, K., Tammaru, T., Pungas, E., and Paas, T. (2012). Emigration After EU Enlargement: Was There a Brain Drain Effect in the Case of Estonia. Tartu: University of Tartu, Faculty of Economics and Business Administration.

Beine, M., Docquier, F., Rapoport, H. (2008). Brain drain and human capital formation in developing countries: Winners and losers. The Economic Journal, 528, pp. 631-652. http://dx.doi.org/10.1111/j.1468-0297.2008.02135.x.

Bernard, T. L. (1970) United States immigration laws and the brain drain. International Migration, 8, pp. 31-38. http://dx.doi.org/10.1111/j.1468-2435.1970.tb01069.x.

Cervantes, M., Guellec, D. (2002). The brain drain: Old myths, new realities. OECD Observer, pp. 40-41.

Docquier, F., Marfouk, A. (2004). Measuring the international mobility of skilled workers (1990-2000): release 1.0. World Bank Policy Research.

Eurostat (2014). Population by sex, age group and citizenship. http://epp.eurostat.ec.europa.eu/portal/page/portal/statistics/search_database (accessed on 18 June 2015).

Friedman, S. (1973). The effect of the US Immigration Act of 1965 on the flow of skilled migrants from less developed countries. World Development., 8, pp. 39-44. http://dx.doi.org/10.1016/0305750X(73)90173-3.

Giannoccolo, P. (2004). The brain drain a survey of the literature. Bologna: Alma Mater Studiorum, University of Bologna, http://amsacta.unibo.it/1577/1/526.pdf.

Gibson, J., McKenzie, D. (2011) Eight questions about brain drain. The Journal of Economic Perspectives, 25, pp. 107-128. http://dx.doi.org/10.1596/1813-9450-5668.

Glytsos, N. P. (2010) Theoretical Considerations and Empirical Evidence on Brain Drain Grounding the Review of Albania's and Bulgaria's Experience. International Migration, 48, pp. 107-130. http://dx.doi.org/10.1111/j.1468-2435.2008.00505.x.

Grubel, H. G. (1968) The reduction of the brain drain: problems and policies. Minerva, 4, 541-558. http://dx.doi.org/10.1007/BF01096547.

Grubel, H. G., Scott, A. D. (1949-61) The immigration of scientists and engineers to the United States, Journal of Political Economy 1966, 4, pp. 368-378. http://dx.doi.org/10.1086/259179.

Grubel, H. G., Scott, A. D. (1966). The International Flow of Human Capital, the Brain Drain. American Economic Review, 56, pp. 268-274.

Grubel, H. G., Scott, A. D. (1967). The characteristics of foreigners in the US economics profession. American Economic Review., 57, pp. 131-145.

Grubel, H., Scott, A. (1977). The brain drain: determinants, measurements and welfare effects. Waterloo: Wilfrid Laurier University Press.

International Economic Association; and Thomas, B. (1958) Economics of International Migrations. London: Macmillan, ISBN: 978-1-349-08443-2.

Johnson, H. G. (1965). The economics of the "brain drain": The Canadian case. Minerva, 3, 299-311, http://dx.doi.org/10.1007/BF01099956. 
Johnson, J. M., Regets, M. C. (1998). International Mobility of Scientists and Engineers to the United States - Brain Drain or Brain Circulation? Arlington, National Science Foundation, Division of Science Resources Studies, http://nsf.gov/statistics/issuebrf/sib98316.htm.

Keely, C. B. (1971). Effects of the Immigration Act of 1965 on Selected Population Characteristics of Immigrants to the United States. Demography, 8, pp. 157-169. http://dx.doi.org/10.2307/2060606.

Keely, C. B. (1975). Effects of U. S. Immigration Law on Manpower Characteristics of Immigrants. Demography, 12, pp. 179-191. http://dx.doi.org/10.2307/2060759.

Özden, Ç., Schiff, M. W. (2006). International migration, remittances, and the brain drain. Washington: World Bank Publications.

Popa. N., Lucheș D. (2014). Etudiant en medicine pour emigrer? Options professionnelles et mobilité territoriale chez les étudiants en médecine de Roumanie, Migrations en Blanc-Médecins d'est en ouest, L'Harmattan, Paris

Romanian College of Physicians, https://www.cmr.ro/ (accessed on 18 June 2015).

Royal Society. (1963). Emigration of Scientists from the United Kingdom. Royal Society.

Spring, J. (2008). Globalization of education: An introduction. New York: Routledge.

Stark, O. (2004). Rethinking the brain drain. World Development, 32, pp. 15-22. http://dx.doi.org/10.1016/j.worlddev.2003.06.013.

The 89th United States Congress (1965). Immigration and Nationality Act, a.k.a. the Hart-Cellar Act 1965. Washington, Public Law. http://library.uwb.edu/guides/USimmigration/1965_immigration_and_nationality_act.html.

United Nations, Department for Economic and Social Affairs, Population Division. (1984). Report of the International Conference on Population: Mexico City, 6 - 14 August 1984. New York: United Nations Publication,

Zimmermann, K. F. (2013). The mobility challenge for growth and integration in Europe. IZA Policy Paper, 69. 